\title{
VENTURE CAPITAL IN CENTRAL AND EASTERN EUROPE - SLOVAKIAN CASE
}

Financing business at the very first stage or expanding it, together with active participation in creating strategies of management, marketing, sales and other fields, may be done by venture capital funds and venture investors. They offer capital, know-how, expertise and assistance and are ready to take significantly higher risk for the average period of 5-7 years. Venture investments are especially effective in stock-oriented markets, due to an opportunity of easy disinvestment through public offering, or in emerging markets, where they meet prospects of very high rates of return. Private equity and venture capital investments may highly support the development of knowledge and innovation, which are among the keys to economic growth and welfare. These investments, rising in Europe, support lowering the development gap between the US and the EU.

\section{Venture capital - an opportunity to develop business and support innovation}

Venture capital (VC) is a method used for encouraging business development at its very first stage, being an important source of equity for start-up companies. It is called the capital of high risk or the business method of setting up a company. Venture capital should be taken into serious consideration when thinking about financing a new business. It may be a great opportunity for small and medium companies who want to develop in the innovation sector but who stand a very small chance of getting a long-term credit due to their low creditworthiness resulting from the lack of experience and rating in a chosen sector of the market.

Investors in venture capital funds are eager to fund start-up companies and to provide them with capital, as well as know-how and advisory services as soon as they recognize the market potential of a given company. They do it with the aim to achieve a high return in the future. They include active investors, involved in management or strategic marketing activities. The usual period of investments is 5-7 years. Before selecting a limited number of companies with favourable investment opportunities, the investors might have to look upon a variety of investment opportunities. They actually invest in just a few of the reviewed businesses - those with excellent technical and business qualities as well as long-term prospectives. The investments can be made during different stages: the start, early development or growth of a business. A venture capital contributor can invest in the phase of "seed investing", that is before the actual product is manufactured or before the company is established, or in its first or second stage of development, which is usually done by providing capital to start up a company. This method is called "early stage investment".

A VC capitalist can be a professionally managed company in the form of limited private partnership or a company closely related with private and public pension funds, endowment funds, foundations, insurance companies, banks, corporations and foreign investors. Wealthy individuals called "angel investors" can also play an important role in VC investments. These are usually people with management expertise, sometimes retired businessmen or businesswomen. They mentor a selected company and provide it with necessary capital and expertise all the way during the company's development. Venture capital investors often diversify the risk by developing a portfolio of young companies in a single venture fund.

VC provides capital to enterprises which are not yet quoted on the stock exchange. When such a company obtains the results which had been previously agreed on regarding the ways of running business and the schedule of actions to be taken to guarantee the stability of the company, the strategic investor withdraws its venture capital. It is done either by obtaining a direct return on capital or by selling the company's shares after introducing the company to the stock market.

Venture capital appears to be more vital and effective in the stock-oriented systems. It seems to be reasonable due to the fact that the relationship between the entrepreneurs and venture capital providers is based on agreements which guarantee the latter the possibility to control the company while the investment is still in progress, and afterwards - the possibility to regain control by the company itself. The operation of regaining control is usually based upon an initial public offering, which gives the venture capitalist a way out of further investments in portfolio companies.

\section{The role of venture capital in economic growth and innovation}

There is an increasing number of successful investments in the region of Central and Eastern Europe (CEE). The results include

\footnotetext{
* Magdalena Markiewicz

The Institute of Foreign Business, Faculty of Economics, University of Gdańsk, Armii Krajowej 119/121, 81-824 Sopot, Poland,

E-mail: magmark@poczta.onet.pl
} 
the rise of competitiveness and employment prospectives and they play a positive role in the development of chosen sectors and have a positive economic impact on all the CEE countries. These enterprises usually become leaders in their markets. The investors contribute the crucial success factors to the financed entrepreneurs. The basic role is played by the capital, but other factors such as know-how, expertise and assistance are of an extreme importance.

In 2001-2003 the rise of venture capital as a way to encourage the development of small and medium-sized enterprises was noted in Europe. The average ratio of investment value to GDP was estimated at the level of $0.36 \%$ of GDP in $2004(0.26 \%$ for buyouts and $0.10 \%$ for venture capital), compared to $0.3 \%$ in 2003 and starting from 2002 it was constantly at the higher level than in the USA. In 2004 the level of start-up investments rose by 13\% as compared to 2003, while investments in high-tech companies increased by $6.5 \%$.

In the years 2000-2003 the performance of venture - grown up companies in the USA demonstrated that venture capital could create market leading companies which contributed significantly to the U.S. economy. Even though they might begin very small, the succeeding ones create new industry sectors and drive economic growth, innovation, and progress. Prominent U.S. companies, being famous examples of ones that had received venture financing early during their growth phases include: Microsoft, Federal Express, AOL, Apple, Office Depot, Intel, Home Depot, Cisco, Compaq, e-Bay, JetBlue, Seagate and Google. The research made in the USA shows that companies receiving venture financing between 1970 and 2003 accounted for 10.1 million jobs and $\$ 1.8$ trillion in revenue in 2003, representing approximately $9.4 \%$ of total U.S. jobs and revenues.

Innovation is recognized as fundamental for economic welfare and GDP growth.

It is observed that a correlation exists between the Summary Innovation Index and GDP per capita, especially when the coun- tries are grouped as of high- and low-income. The relationship between the income and innovation seems to be stronger at lower GDP levels and is more differentiated at higher levels of GDP.

Due to the fact that VC is regarded as vital for innovation, it is annually analysed within the European Innovation Scoreboard (EIS). EIS is an instrument developed by the European Commission used since resolving the Lisbon Strategy for evaluation and comparison of innovation performance in the Member States, candidate countries, Norway, Switzerland, USA and Japan. In 2004 the SII indicated among the first five positions: Japan as the most innovative country, then Finland and Sweden representing the EU, and finally the US and Switzerland. The most innovative among the New Member States are Estonia and Slovenia, ranking above some of the EU15 countries. The most innovative sectors in EU are electrical and optical equipment, chemical products and transport equipment industries.

The EIS is based on 20 indicators combined into the Summary Innovation Index (SII). The main drivers and effects of innovation are: human resources, creation of knowledge, the transmission and application of knowledge and finally - innovation finance, output and markets. From the point of view of venture capital the most important group of indicators would be the last one, but the first three are complementary to it and they are also extremely important for the development of venture capital.

The innovation finance, output and markets group consists of six indicators: share of high-tech venture capital investment, share of early stage VC in GDP, percentage of total turnover of product sales ("new to market" or "new to the firm but not the market"), internet access, ICT expenditures and share of manufacturing valueadded in high-tech sectors. The definitions of the indicators have been specified by Eurostat (excluding the first one, given by EVCA).

High-tech venture capital share in EU15 was at quite a high level and European leaders were Denmark, Germany and France.

GDP growth in CEE countries in 2001-2006 [\%, change to previous year]

Table 1

\begin{tabular}{|l|c|c|c|c|c|c|c|c|}
\hline & 2001 & 2002 & 2003 & 2004 & $\begin{array}{c}2005 \\
\text { - forecast }\end{array}$ & $\begin{array}{c}2006 \\
\text { - forecast }\end{array}$ & $\begin{array}{c}\text { 2004 } \\
\text { Summary } \\
\text { Innovation } \\
\text { Index }\end{array}$ & $\begin{array}{c}\text { GDP per } \\
\text { capita, } \\
\text { 2004 (EUR) }\end{array}$ \\
\hline Czech Republic & 2.6 & 1.5 & 3.7 & 4.0 & 3.7 & 3.9 & 0.27 & 8,430 \\
\hline Hungary & 3.8 & 3.5 & 2.9 & 4.0 & 3.8 & 4.0 & 0.25 & 7,960 \\
\hline Poland & 1.0 & 1.4 & 3.8 & 5.3 & 4.2 & 4.7 & 0.14 & 5,100 \\
\hline Slovakia & 3.3 & 4.4 & 4.2 & 5.5 & 4.6 & 4.8 & 0.24 & 6,140 \\
\hline Slovenia & 2.7 & 3.4 & 2.5 & 4.6 & 3.8 & 4.0 & 0.32 & 12,980 \\
\hline
\end{tabular}

Source: Based upon: European Innovation Scoreboard 2004. Comparative Analysis of Innovation Performance, Commission Staff Working Paper, Commission of the European Communities, Brussels, SEC(2004) 1475, 19 November 2004, p.9; CEE Report. Business Information on Central and Eastern Europe, no.2/2005, Economic Research, http://economicresearch-e-ba-ca.com.pdf, p. 22; CEE Economic Data. Outlook for 2006, Issue 1, Bank Austria Creditanstalt, http://economicresearch-e-ba-ca.com.pdf, p. 10-32. 


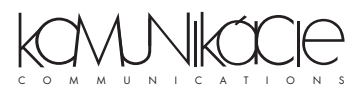

The highest ratio of early-stage venture capital to GDP was observed in Switzerland, Finland and Denmark.

From 2000, the year when the Lisbon Strategy started till the end of 2003, the European private equity and venture capital industry financed over 40000 companies and thus formed new industries contributed to creating 6.5 million jobs and brought 415 companies to the stock market. In 2003 the private equity industry raised 27 billion EUR from institutional investors and invested 29.1 billion EUR in the growth of European companies. In 2004 these figures reached 27.5 billion EUR of raised funds and 36.9 billion EUR of investments accordingly (which was the record value and which surpassed the peak value of 35 billion EUR reached in 2000).

The innovation gap between the United States and Europe is still high. It results from the low rate of patents registered in Europe ( $50 \%$ of the innovation gap), working population with tertiary education (26\%) and R\&D expenditures, mainly business R\&D (11\%), high tech manufacturing (11\%) and early-stage venture capital (10\%).

\section{Barriers to development of venture capital sector}

The barriers to development of that sector are the same or similar in most of the EU countries. In 1998 European Commission identified those handicaps within Risk Capital Action Plan (RCAP) focused on the integration of financial markets within the EU countries. The most important barriers are:

- insufficient knowledge about this way of financing, alternative to bank credits,

- the lack of adequate institutional and legal regulations defining multilateral aspects of investment activities, functioning of VC funds and such institutional investors as investment fund and pension funds,

- low range of integration of capital markets within the EU, together with their low capitalization and liquidity,

- disharmonisation of tax systems, which may discourage potential investors, especially business angels - sophisticated private investors providing their capital, from investing into venture capital and private equity funds,

- legal limits of investments in VC by pension funds.

Risk Capital Action Plan is known, together with the Financial Services Action Plan, as a constituent of the Lisbon Strategy. It is aimed at developing capital markets, essential for financing small and medium sized enterprises, through implementation of the legal framework, both on the central level of the European Union and on the level of Member States. The reports of the European Commission indicate positive results, however pointing at the development gap between the EU and the USA, with particular stress on diversification of tax systems, which also complicates the use of venture capital.

The issue of bridging the gap is represented by the innovation trend presented in Fig. 1: the trend is rising for Japan as well for

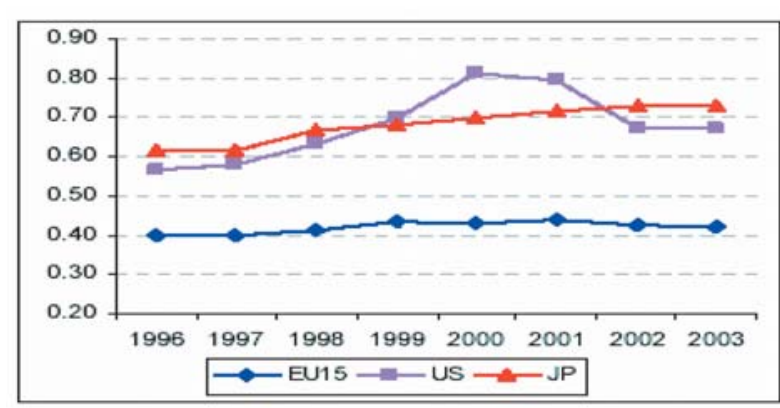

Figure 1. The innovation gap between the USA and the EU measured by Summary Innovation ndex in 1996-2003.

Source: European Innovation Scoreboard 2004. Comparative Analysis of Innovation Performance, Commission Staff Working Paper, Commission of the European Communities, Brussels, SEC(2004) 1475, 19 November 2004, p. 4.

the US (after a slump in 2002), where the peak in innovation performance was reached in 2000-2001 thanks to venture capital achievements. In Europe this trend seems to remain stable. The reports recognize the important role of private equity and venture capital in making Europe a more attractive place to invest and work. There is no doubt that the PE/VC funds may reduce the gap through enhancing research opportunities and providing the companies and the markets with patents. Patents may mean both technical improvements and such non-technical changes like reshaping organization in order to get the most profits from new technologies (thus it may bring about changes in the organizational structure, management techniques and aesthetic appearance).

\section{Venture capital in Central and Eastern Europe}

Private equity and venture capital funds are important part of the CEE capital markets in spite of the relatively young experience in the region. The fund raising and investments started in CEE countries in 1990. The development processes of venture capital in CEE countries were encouraged by public and financial institutions like European Bank for Reconstruction and Development (EBRD) or European Investment Fund (EIF). They invested primarily in early to mid-stage small and medium enterprises. Their actions concern almost all of CEE countries. For instance, until July 2004, EIF has committed in CEE countries 115 million EUR in 8 venture capital funds investing in Bulgaria, the Czech Republic, Estonia, Hungary, Latvia, Lithuania, Poland, Romania, Slovakia and Slovenia. It is estimated that within 15 years more than 7 billion EUR were raised to the funds and in 2003 fundraising activity increased by $28 \%$ in all CEE countries.

Appreciating the important role of venture financing in creating the economic growth, European Venture Capital Association (EVCA) established in 2003 Central and Eastern Europe Task Force aimed at the development and promotion of private equity and venture capital in the region. 


\begin{tabular}{|c|c|c|c|c|c|c|c|c|}
\hline EUR,000 & $\begin{array}{c}\text { Czech } \\
\text { Republic }\end{array}$ & Hungary & Poland & Romania & Slovakia & Baltic States & Other* & Total CEE \\
\hline Domestic & 12.672 & 16.365 & 5.242 & 535 & 1.539 & 52.859 & 34.942 & 124.154 \\
\hline Other European & 35.365 & 16.994 & 19.245 & 5.144 & 335 & 50.836 & 0 & 127.919 \\
\hline Non-European & 45.730 & 6.546 & 1.250 & 2.890 & 1.444 & 2.023 & 0 & 59.883 \\
\hline Total 2003 & 93.767 & 39.905 & 25.737 & 8.569 & 3.318 & 105.718 & 34.942 & 311.956 \\
\hline Total 2002 & 55.777 & 31.533 & 108.763 & 12.673 & 9.891 & 2.111 & 22.296 & 243.044 \\
\hline
\end{tabular}

Source: EVCA

* Bulgaria, Croatia, Slovenia

Type of investment by CEE country in 2003

Table 3.

\begin{tabular}{|l|c|c|c|c|c|c|c|c|}
\hline \multicolumn{1}{|c|}{ EUR,000 } & & $\begin{array}{c}\text { Czech } \\
\text { Republic }\end{array}$ & Hungary & Poland & Romania & Slovakia & Baltic States & Other* \\
\hline Seed & & 1 & 0 & 166 & 0 & 0 & 0 & 600 \\
\hline Start-up & & 1.378 & 753 & 2.842 & 0 & 0 & 832 & 18.428 \\
\hline Expansion & & 25.421 & 19.986 & 39.952 & 49.887 & 4.479 & 131 & 5.528 \\
\hline Replacement capital & & 0 & 1.759 & 42.199 & 519 & 0 & 6.730 & 0 \\
\hline Buyouts & & 12.624 & 88.257 & 92.054 & 31.614 & 0 & 2.307 & 0 \\
\hline Total 2003 & & 39.422 & 110.755 & 177.213 & 82.020 & 4.479 & 10.000 & 24.556 \\
\hline Total 2002 & & 27.370 & 75.747 & 137.238 & 18.008 & 4.737 & 2.902 & 7.726 \\
\hline
\end{tabular}

Source: EVCA

* Bulgaria, Croatia, Slovenia

Investors in CEE countries usually represent foreign capital, but the domestic capital is also invested in the region. Investments concentrated in the field of telecommunication, consumer goods and services, media and financial services $(66 \%$ of the venture capital investment value) and an analogical tendency could be observed all over Europe.

The important aspect of those investments is the high rate of start-up and early-stage financing capital. The governments in the region make efforts to stimulate such activities. However, it varies in different countries of the region. Early-stage investments are still low in comparison to most of Europe, which creates "an equity gap” for early-stage CEE entrepreneurs.

The average size of investment reflects the increasing trend in the CEE countries, since the companies develop, and is similar to the one visible in the whole Europe. Average European VC investment size was 2.8 million EUR in 2003 and it increased to 3.6 million EUR in 2004. However, the figures concerning the GDP growth show that the CEE countries have still greatly lower GDP per capita than previous 15 Member States (it is a factor of 4 times). Political, administrative, economic and legal reforms offer a chance to improve these factors.

\section{Slovakian experience with venture capital}

In Slovakia there exist few private equity and venture capital funds, among the first were: the Slovak American Enterprise Fund (SAEF), EBRD Post-Privatisation Fund, the Phare-Funded Seed Company and Genesis Capital operating for Advent International.

A good example of using the described way of financing in Slovakia is Slovpack, a manufacturer of plastic packaging for food and industrial construction sectors. The private equity investor was in that case Raiffeisen Ost Invest (ROI), providing the company with 1.1 million EUR from 1998 to 2002 . The company started to exist in 1994 and until 1998 did not have a clear business strategy and complicated formal structure made internal relations and management decisions ineffective. Raiffeisen Ost Invest prepared a management buyout and stated the company's progress using the extensive experience of an earlier team within a five-year strategic plan. The strategy was based on cooperation with the second strategic partner (Slovnaft) and included diversification of products, increase in product quality, improving financial control systems and adjusting the production to the clients' demands and orders. From 1998 to 2002 Slovpack achieved 10 million EUR sales and 2 million EUR EBITDA, its productivity increased by $30 \%$. The company was a leader in the Slovakian market and exported to Germany, the Netherlands, Austria, the Czech Republic and Poland. 


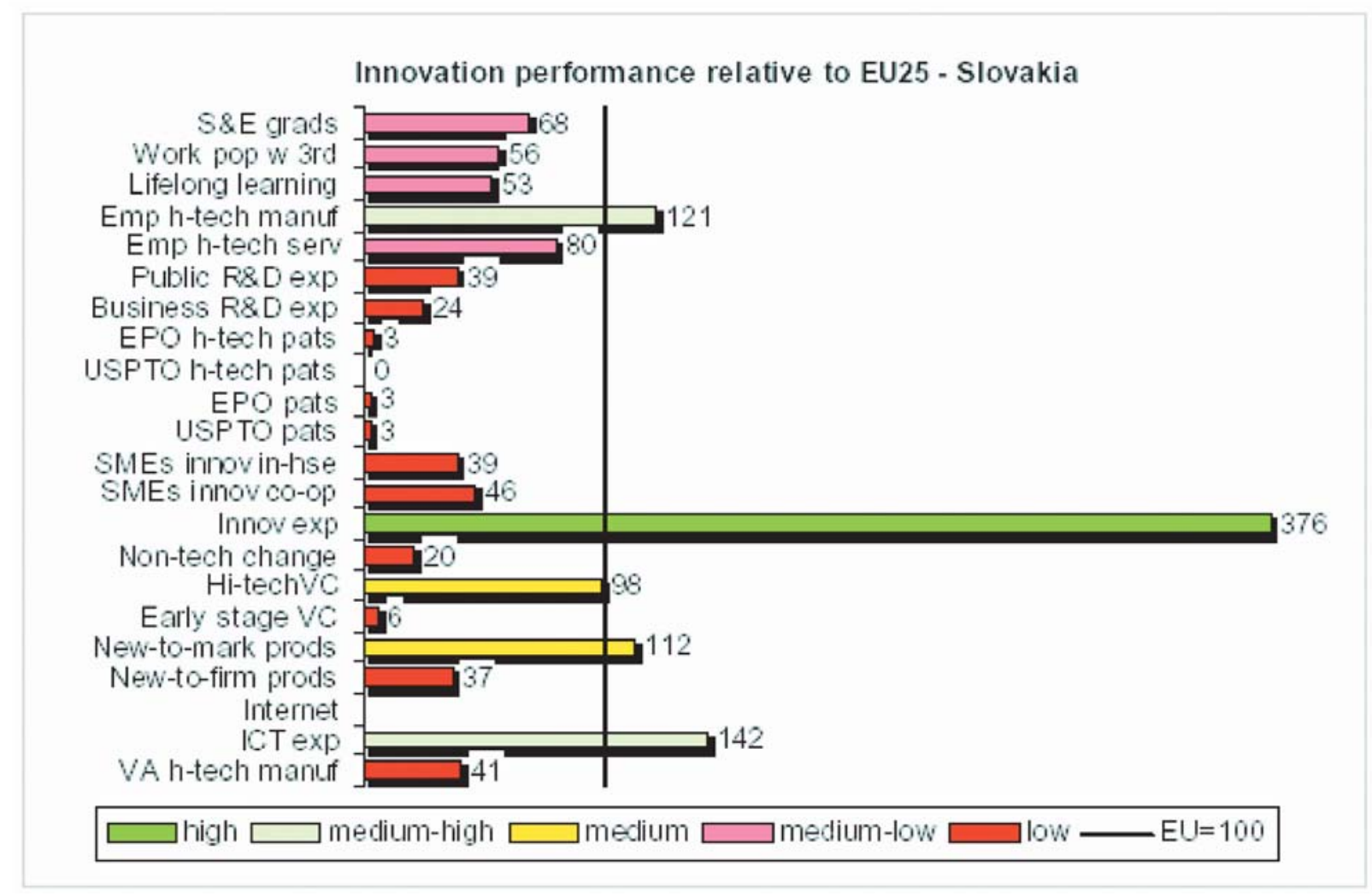

Figure 2. Innovation performance relative to EU25 - Slovakia

Source: 2004 European Innovation Scoreboard. Country Pages, EU25 + Candidate Countries, Commission Staff Working Paper, Commission of the European Communities, Brussels, SEC(2004) 1475, 19.11.2004, p. 44.

Abbreviations in Figure 2:

$S \& E$ grads - science and engineering graduates; work pop $w 3 \mathrm{rd}$ - population with tertiary education; emp - employment; $h$-tech - high technology; manuf - manufacturing; serv - services; $R \& D$ - research and development; exp - expenditures; EPO - European Patent Office; USPTO - US Patent and Trade Office; pats - patents; $S M E$ - small and medium enterprises (a number of firms); in-hse - introducing innovation in house, as a single firm; co-op - in cooperation agreements with other enterprises or institutions; innov exp - innovation expenditure as \% of all turnover; non-tech change - share of SME using non-technical change in all SMEs; ICT exp - total expenditures on information and communication technology; VA h-tech manuf - total value-added in manufacturing in five high technology industries (pharmaceuticals, office equipment, telecommunications and related equipment, instruments, aerospace).

In 2002 Raiffeisen Ost Invest disinvested from Slovpack realizing an IRR of $32 \%$.

According to EVCA Final Activity Figures, in 2004 private equity funds in Slovakia raised 5,256 million EUR and 4,224 million EUR was invested. The amount of disinvestments was estimated at the level of 1,321 million EUR. These numbers are not high when compared to other European countries (0.0002 of raised funds and 0.0001 of private equity investments). Slovakia is the smallest market within the CEE countries and previously (up to 2000) it was often omitted by investors who were interested rather in the Czech Republic, Hungary and Poland.

Since then the political and economic situation started to be more stable and the government made many incentives to attract foreign direct investments. Now FDI are high also due to low labour costs, highly educated labour force and the flexibility of the workers. The excellent example is automotive sector with Volkswagen, PSA Peugeot Citroen, Renault, Hyundai Motor (Kia brand), all producing the most modern models in Bratislava, Trnava, Kolin, Nove Mesto and Žilina. The Slovakian factories have now even bigger capacity than the factories in its CEE neighbours.

However, venture capital exists in a different way - the government has less direct economic tools to enhance the growth of $\mathrm{VC}$ and in many Slovakian enterprises keeping control is one the most important issues put ahead of capital risk.

Despite this fact, the Slovakian market puts itself high in 2004 European Innovation Scoreboard (EIS) regarding ICT expenditures and employment in medium- and high-tech manufacturing, where the figures show accordingly a 15 and $25 \%$ positive differ- 
ence from the EU trend growth. It is a bit different with public R\&D, which are only stated as "catching up" and with business R\&D having status "fallen further behind" at EIS. Performance of high-technology venture capital in Slovakia was estimated at the average level achieved in EU25, while early stage venture capital is still very low, at the level of 6\% of the EU25 (Figure 2).

High-tech venture capital includes computer-related fields, electronics, biotechnology, medical and health, industrial automation and financial services. The measurement concerns the sum of seed and start-up capital as well as expansion capital. These investments reflect strong annual fluctuations, which are neglected when using a two-year time of observation.

When calculating the share of early stage venture capital, the institutions take into consideration both seed (financing the research, assess and growth of an original concept) and start-up capital (product development, initial marketing, manufacturing and sales). The transactions of management buyouts, management buyin or venture purchase of quoted shares are excluded.

Non technical change means changes in organizational structures, management techniques and product design, estimated as low in Slovakia.

The strongest point of the Slovakian market was innovation expenditures, which even exceeded those of EU25. The scoreboard for 2004 implied the first rank in that section among all the Member States.

\section{Conclusions}

The economic growth of the CEE region is expected to rise as a consequence of increasing investment opportunities for private equity and venture capital funds, financing the companies which participate in the economic development of the region. As stated by the European Venture Capital Association: "European private equity and venture capital provides a vital source of long-term investment capital for growing companies across all industry sectors. It contributes to sustainable economic growth, generating employment, financing new research and technologies and supporting Europe's promising growth companies. VC operates according to accepted standards of conduct, reporting and valuation and has a strong network of professional advisors to support its increasingly important role in the European economy".

The important result of using VC financing is the rise in the number of patents, increased support for $R \& D$ and lowering the innovation gap between the United States, Japan and Europe. The general strapping trends in the CEE countries are partly explained by the lower starting point as compared to the former EU15. However, the most important fact is that the CEE countries have important achievements in introducing innovative concepts, which may be of a great importance since those results are worse as regards the proportion of GDP they represent. Financing innovation may lead to higher GDP and therefore better GDP-related results in the future.

\section{References}

[1] 2004 European Innovation Scoreboard. Country Pages, EU25 + Candidate Countries, Commission Staff Working Paper, Commission of the European Communities, Brussels, SEC(2004) 1475, 19 November 2004

[2] BANCE, A.: Why and how to invest in private equity, EVCA Investor Relations Committee Paper, March 2004

[3] BLACK, B. S., GILSON, R. J.: Venture capital and the structure of capital markets: banks versus stock markets, Journal of Financial Economics, Volume 47, Issue 3, March 1998

[4] Central and Eastern Europe Success Stories, EVCA, Special Paper, October 2004

[5] Commission Report on Lisbon Strategy, EVCA Comment, Brussels, 2 February 2005

[6] EDMONDSON, G.: Detroit East, "Business Week”, European Edition, 25 July - 1 August 2005

[7] European Innovation Scoreboard 2004. Comparative Analysis of Innovation Performance, Commission Staff Working Paper, Commission of the European Communities, Brussels, SEC(2004) 1475, 19 November 2004

[8] HOLT, E.: Venture capital bypasses Slovakia, "Slovak Spectator", Vol. 6, Nr 18, 8-14 May 2000, www.slovakspectator.sk, 5 August 2000

[9] EVCA Final Activity Figures for 2004, Thomson-PriceWaterhouseCoopers, London, 16 June 2005

[10] Implementation of the Risk Capital Action Plan, Commission Communication of 11 May 1999, COM (1999) 232

[11] Rozwój systemu finansowego w Polsce w latach 2002-2003, National Bank of Poland, Warsaw, December 2004

[12] Venture Impact 2004: Venture Capital Benefits to the U.S. Economy, National Venture Capital Association, www.nvca.org 